\title{
EVALUATION OF THREE CANOLA (BRASSICA NAPUS L.) CULTIVARS FOR YIELD AND SOME QUALITY PARAMETERS UNDER THE ENVIRONMENTAL CONDITION OF SOUTHEASTERN ANATOLIA, TURKEY
}

\author{
OZTURK, F. \\ Department of Field Crops, Faculty of Agriculture, University of Sirnak, 73300 Şirnak, Turkey \\ (e-mail: fozturk@sirnak.edu.tr; phone: +90-532-254-0197; fax: +90-486-551-3031) \\ (Received 20 $0^{\text {th }}$ Nov 2018; accepted $11^{\text {th }}$ Jan 2019)
}

\begin{abstract}
Canola is a significant alternate oilseed crop in Southeastern Anatolia, Turkey. While, there is no evidence for good yield potential canola cultivars are available in this area. Therefore, the study was conducted with three canola cultivars in consecutive two seasons (2013-14 and 2014-15) to find out the appropriate canola cultivars which are suitable to grow under the environmental condition of Southeastern Anatolia, Turkey. The experiment was carried out in a randomized complete block design with three replications. After two years of observation, it was found that plant height and branches plant ${ }^{-1}$ of all cultivars were varied significantly in both years. Considering the growing season, the maximum seed yield (2593.7 kg ha-1) was recorded in the first season (2014-15), while the minimum was recorded in the second season (2015-16). Among the cultivars, seed yield varied significantly and the maximum seed yield (2617.1 kg ha-1) was achieved in the variety 'Licrown'. The variety, 'Licord' was produced the highest oil content $(37.92 \%)$ and protein $(22.48 \%)$, while, variety 'Express' achieved the lowest oil content $(37.43 \%)$. The greatest palmitic acid (4.67\%), stearic acid (2.06\%) and oleic acid $(65.5 \%)$ content were produced by the variety 'Express'. While the variety 'Licord' produced the smallest value of stearic acid (1.86\%), linoleic acid (17.17\%). The variety 'Express' produced the lowest saturated fatty acid content $(12.63 \%)$, while, the variety 'Licrown' achieved the highest $(12.97 \%)$, although, the variety 'Licrown' produced the lowest $(85.14 \%)$, and variety 'Express' produced the highest $(85.47 \%)$ unsaturated fatty acid content. It is concluded that all cultivars have a good potential for the winter season of Southeastern Anatolia of Turkey. Accordingly, in the future the cultivar 'Express' could be used as a cultivar with high oleic and linoleic acid content and high yield under investigation conditions.
\end{abstract}

Keywords: canola, genotypes, oil composition, saturated fatty acid, unsaturated fatty acids, yield

\section{Introduction}

Canola (Brassica napus L.) is an essential oil seed crop in the world. Its oil is used as biofuel, human consumption (edible oil), feeding animals, and used in chemical and pharmaceutical industries (Friedt and Snowdon, 2009). It belongs to the family of Brassicaceae, which is becoming one of the major sources of the vegetable oil in the world (Baghdadi et al., 2013). It is the second largest oil seed after soybean worldwide, producing high-protein meal used for animal feed during processing (FAO, 2018). Presently, over $50 \%$ of vegetable oil, consumed in Turkey, is imported from abroad (İkiel and Kaymaz, 2005). To reduce the gap between oil consumption and the production of oilseed in Turkey, it is essential to grow alternate oilseed crops such as canola in crop rotation system in this region. Thus, the supplementary production of oilseed can meet up vegetable oil, increase biodiesel production, and decrease the import of vegetable oil (Öztürk, 2010; Cosgun and Öztürk, 2014).

Canola is a specific type of rapeseed correlated with high quality oil and meal. It is a special type of rapeseed that have less than $2 \%$ erucic acid in the oil and less than 30 micromoles per gram of glucosinolates in the oil-free meal (Anonymous, 2002). Moreover, canola contains $40-45 \%$ oil and $39 \%$ protein, and oil contains a desirable 
profile of saturated fatty acids $(\sim 7 \%)$, high level of unsaturated fatty acids like oleic acids $(61 \%)$ and medium level of linoleic acid $(21 \%)$ and linolenic acid $(11 \%)$ (Molazem et al., 2013; El Sabagh et al., 2017; El Sabagh et al., 2018; Joughi et al., 2018). Hence, it represents a healthy edible oil. Oil seed of canola provide over $13.2 \%$ of edible oil in the world (Eskandari and Kazemi, 2012; Joughi et al., 2018). Gheorghe et al. (2013) found that grain yields significantly differences among fifty rapeseed cultivars grown under Romanian conditions. The agronomic management factors influenced the yield of the crop (Anonymous, 1992) and the cultivars with high yield potential play an important role in the increase of the yield per unit area (Sana et al., 2003). However, winter canola is a relatively new crop for Turkey, but the suitable cultivars for winter canola have not yet been established for this region of study (Coşgun and Öztürk, 2014). Therefore, in this study we considered three cultivars to evaluate the varietal performance of these cultivars, considering agronomic characteristics, oil quantity and quality parameters in Southeastern Anatolia of Turkey.

\section{Materials and methods}

\section{Location, duration, edaphic and climatic conditions}

Two field experiments were conducted during 2013/14 and 2014/15 growing seasons at the research area of Dicle University to evaluate the yield and quality properties of some canola cultivars in the Southeastern Anatolia region of Turkey. Soil samples at sowing were analyzed and was observed the soil was classified as clay (71.6\%), $1.25 \%$ organic matter, Available Phosphorus $1.63 \mathrm{~kg} / \mathrm{da}, 13.02 \%$ alkaline, $0.01-0.02 \%$ salt and $7.73 \mathrm{pH}$. The average, and minimum temperatures, monthly rainfall and relative air humidity data for 2013/2014-2014/2015 during the canola vegetation period are presented in (Fig. 1).

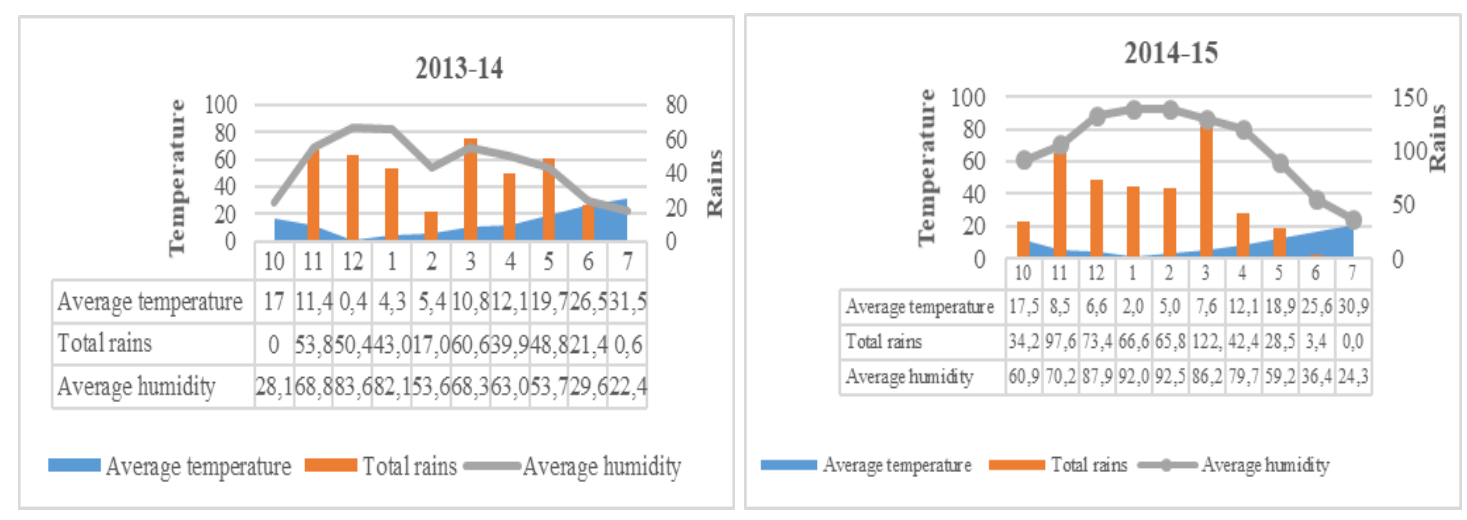

Figure 1. Monthly average air temperatures ${ }^{\circ} \mathrm{C}$, totally rains ( $\mathrm{mm}$ ) and humidity (percentage), respectively during the growing seasons

The monthly rainfall, humidity and average temperatures for 2013-14 and 2014-15 within the growing period of canola (October-May) are presented in Figure 1.

The average temperature was around $14.5^{\circ} \mathrm{C}$. The average rainfall was $42.07 \mathrm{~mm}$. The highest rainfall was observed in March in 2013-14 as $60.6 \mathrm{~mm}$ and in March in 2014-15 as $122.2 \mathrm{~mm}$. Air temperatures and humidity were close to the long term averages during the two growing seasons and but annual rainfall is different in the 
experimental years. 2013-14 growing season was a relatively dry year and monthly rainfall during the growing season (October-May) were lower than 2014-15 and longterm averages. Frost damage was not seen in 2014 and 2015 years.

\section{Experimental design, plant materials, treatments and experimentation}

The experimental area is located $\left(37^{\circ} 532588 \mathrm{~N}, 40^{\circ} 162356 \mathrm{E}\right)$ at $670 \mathrm{~m}$ above sea level. The field experiments were arranged in a randomized complete block design with three replications. Three canola (Brassica napus L.) cultivars i) Express, ii) Licord, and iii) Licrown were used as material in this study, which these cultivars are consider the most preferred are variants in Turkey. It has been used to determine the most suitable cultivars in southeastern of Anatolia. The area of each plot was including 6 rows with $0.7 \mathrm{~m}$ row distance, $5 \mathrm{~m}$ row length, plants in the row were $5 \mathrm{~cm}$ apart from each other and seed rate of $60 \mathrm{seed} \mathrm{m}^{-2}$. All plots were received at $36 \mathrm{~kg} \mathrm{~N} \mathrm{ha}^{-1}$ and $92 \mathrm{~kg} \mathrm{P}_{2} \mathrm{O}_{5}$ ha-

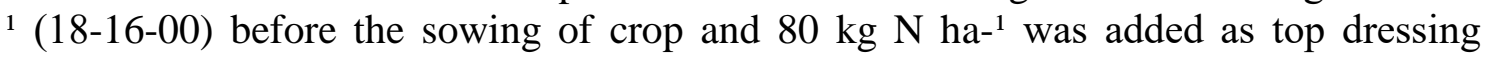
during stem elongation. The source of $\mathrm{N}$ was ammonium nitrate $(33 \% \mathrm{~N})$. The crop was sown on October 20 in both years (2013/14 and 2014/2015). The crop was harvest on June 20 in both years (2013/14 and 2014/15).

\section{Data collection}

Yield attributes: Randomize selected 10 plants each plot. Plant height, branch number, pod number and seed number. 1000-seed weight, and seed yield were examined. Plants were harvested $11.2 \mathrm{~m}^{2}$. Seed yield $\left(\mathrm{kg} \mathrm{ha}^{-1}\right)$ was calculated from the plants of the four ridges in each plot and the yield per hectare was measured.

\section{Quality properties}

Oil content, protein content and Fatty acid content: Protein content (\%) was measured by Kjeldahl method (AOAC, 2000). Oil content (\%) was measured by Soxhlet instrument with $\mathrm{n}$-hexane $\left(60^{\circ} \mathrm{C}\right)$ as organic solvent. Fatty acid compositions of seeds were measured with a gas chromatography and the analyses were performed at the central laboratories of Tubitak-Mam (Marmara Research Center) according to the method described by Slover and Lanza (1979).

\section{Statistical analysis}

Data for the experiment was analysed by JMP 5.0 software program for comparison of data was analyzed by JMP package program Mean tested by Tukey at the $1 \%$ level.

\section{Results and discussion}

\section{Agronomic traits}

The results of ANOVA for agronomic traits are presented in Table 1. Statistical analysis for the yield attributes, the analysis of variance, year, and year $\mathrm{x}$ cultivar interactions were found significant on the plant height, and the number of branches per plant except for pod number, seed number, 1000-seed weight and seed yield. Moreover, the cultivars were insignificant for all parameters. According to the mean of two years were revealed that, the highest number of pod (122.5) was produced from Licrown and the lowest value (112.2) was produced from Express. These findings showed that, the 


$$
-2170 \text { - }
$$

highest value of seed number was achieved from Expres with 25.9, while the lowest value was produced from Licrown with 24.5 (Table 2).

Table 1. Analysis of variance and means of some yield traits of canola genotypes

\begin{tabular}{l|c|c|c|c|c|c|c}
\hline $\begin{array}{c}\text { Source of } \\
\text { variation }\end{array}$ & Df & $\begin{array}{c}\text { Plant height } \\
(\mathbf{c m})\end{array}$ & $\begin{array}{c}\text { Pod } \\
\text { number/plant }\end{array}$ & $\begin{array}{c}\text { Seed } \\
\text { number/pod }\end{array}$ & $\begin{array}{c}\text { 1000-seed } \\
\text { weight (g) }\end{array}$ & $\begin{array}{c}\text { Branch } \\
\text { number/plant }\end{array}$ & $\begin{array}{c}\text { Seed yield } \\
\left(\mathbf{k g ~ h a}^{-1}\right)\end{array}$ \\
\hline Block (B) & 2 & - & - & - & - & - & - \\
Years (Y) & 1 & $* *$ & $\mathrm{~ns}$ & $\mathrm{~ns}$ & $\mathrm{~ns}$ & $*$ & $\mathrm{~ns}$ \\
Cultivars (C) & 2 & $\mathrm{~ns}$ & $\mathrm{~ns}$ & $\mathrm{~ns}$ & $\mathrm{~ns}$ & $\mathrm{~ns}$ & $\mathrm{~ns}$ \\
Y $\times$ C & 2 & $*$ & $\mathrm{~ns}$ & $\mathrm{~ns}$ & $\mathrm{~ns}$ & $*$ & $\mathrm{~ns}$ \\
Error & 10 & & & & & & \\
CV & & 10.04 & 11.33 & 6.17 & 6.96 & 19.09 & 8.46 \\
\hline
\end{tabular}

ns: not significant, *significant at $\mathrm{P}<0.05, * *$ significant at $\mathrm{P}<0.01$

Table 2. Response of canola cultivars on seed yield attributes and yield

\begin{tabular}{l|c|c|c|c|c|c|c|c|c}
\hline \multirow{2}{*}{ Cultivars } & \multicolumn{3}{|c|}{ Plant height (cm) } & \multicolumn{3}{c|}{ Pod number/plant } & \multicolumn{3}{c}{ Seed number/pod $^{\mathbf{1}}$} \\
\cline { 2 - 10 } & $\mathbf{2 0 1 3 / 1 4}$ & $\mathbf{2 0 1 4 / 1 5}$ & Mean & $\mathbf{2 0 1 3 / 1 4}$ & $\mathbf{2 0 1 4 / 1 5}$ & Mean & $\mathbf{2 0 1 3 / 1 4}$ & $\mathbf{2 0 1 4 / 1 5}$ & Mean \\
\hline Express & 124.7 b & 121.1 & 122.9 & 112.4 & 112.1 & 112.2 & 25.9 & 25.9 & 25.9 \\
Licord & 154.2 a & 124.2 & 139.1 & 105.6 & 121.1 & 113.3 & 26.2 & 24.6 & 25.4 \\
Licrown & 159.2 a & 120.4 & 139.8 & 127.2 & 117.9 & 122.5 & 25.3 & 23.7 & 24.5 \\
Mean & 146.0 a & 121.9 & 133.9 & 115.1 & 117.0 & 116.0 & 25.8 & 24.7 & 25.3 \\
LSD $_{\text {caultivars }}$ & 22.29 & - & - & - & - & - & & & \\
LSD $_{\text {year }}$ & \multicolumn{2}{|c|}{13.81} & & - & - & - & & & \\
\hline
\end{tabular}

\begin{tabular}{l|c|c|c|c|c|c|c|c|c}
\hline \multirow{2}{*}{ Cultivars } & \multicolumn{3}{|c|}{ 1000-seed weight $(\mathbf{g})$} & \multicolumn{3}{c|}{ Branch number/plant } & \multicolumn{3}{c}{ Seed yield (kgha-1) } \\
\cline { 2 - 10 } & $\mathbf{2 0 1 3 / 1 4}$ & $\mathbf{2 0 1 4 / 1 5}$ & Mean & $\mathbf{2 0 1 3 / 1 4}$ & $\mathbf{2 0 1 4 / 1 5}$ & Mean & $\mathbf{2 0 1 3 / 1 4}$ & $\mathbf{2 0 1 4 / 1 5}$ & Mean \\
\hline Express & 3.27 & 3.34 & 3.31 & 3.7 & 2.8 & 3.25 & 2317 & 2560 & 2439 \\
Licord & 3.38 & 3.57 & 3.47 & 4.0 & 2.9 & 3.45 & 2285 & 2652 & 2468 \\
Licrown & 3.27 & 3.58 & 3.42 & 3.6 & 3.3 & 3.45 & 2665 & 2568 & 2617 \\
Mean & 3.31 & 3.50 & 3.40 & 3.8 a & 3.0 b & 3.40 & 2422 & 2593 & 2508 \\
LSD $_{\text {cultivars }}$ & - & - & - & - & - & - & - & - & - \\
LSD $_{\text {year }}$ & - & & - & \multicolumn{2}{|c|}{0.7} & - & - & - & - \\
\hline
\end{tabular}

In each column, means followed by the same letter within columns are not significantly different $(\mathrm{P}<0.01)$ according to Tukey test, ns: not significant

Considering the average two years yield, the greatest seed yield was achieved from second (2014-15) growing season with $2593.7 \mathrm{~kg} \mathrm{ha}^{-1}$ and the minimum seed yield was achieved in first (2013-14) growing season. Regarding the averages, the difference between cultivars were statistically non-significant in terms of seed yield and the highest seed yields were produced from cultivar 'Licrown' $\left(2617.1 \mathrm{~kg} \mathrm{ha}^{-1}\right)$ in Table 2. Several factors affect the seed yield and yield attributes in crop, including cultivar, seasonal variation, location, planting date, soil nutrient, moisture availability, growing conditions in different crops (Abdelaal et al., 2017; Barutçular et al., 2017; Gormus et al., 2017a, b). Zhang et al. (2011) who pointed out the seed yield of different canola cultivars was significantly varied among them. Also, El Habbasha and El salam (2009) observed that there are significant differences among canola cultivars on the seed yield. It was assessed several genotypes of Brassica napus L. and found significant 
differences for some yield attributes. Likewise, various investigators studied for various mustard and canola cultivars, and observed the seed yield differences among the cultivars were significantly (Khehra and Singh, 1988; Stingram et al., 2002).

\section{Quality traits}

The statistical analysis (ANOVA) of data of quality traits are presented in (Table 3). It was observed that, the cultivars differed significantly and various cultivars nonsignificant in in oil quality traits. The means of some of quality properties of canola cultivars are given (Table 4). As it can be seen from (Table 4), the oil and protein content among peanut varieties was significant, the cultivar Licord was recorded the highest oil content $(37.92 \%)$ and protein $(22.48 \%)$, while, the cultivar Express was produced the lowest oil content $(37.43 \%)$. Oil content of canola depends on several factors such as variety, growth environment, agrotechnics and fertilization (Laaniste et al., 2004; Coşgun and Öztürk, 2014). It was found that the oil and protein percentage in various crops depending on genotype and growing conditions, and influenced by genotype, climatic conditions, geographical location, growing season and growing conditions (Y1ldırım et al., 2018; Akdeniz et al., 2018a,b). Oil content is negatively related with protein content (Gül et al., 2005). Although, protein content may be affected by environments, they differ due to the genetic properties (Atakişi, 1977).

Generally, more work required to enhance oil quality among canola cultivars under investigation conditions. The main aims in canola breeding to reduction the long chain and saturated fatty acids in canola cultivars. Statistically significant differences among cultivars were found for fatty acids. The saturated fatty acids content in canola oil were affected by cultivars, the greatest value of palmitic acid $(4.67 \%)$, stearic acid $(2.06 \%)$ and oleic acid $(65.5 \%)$ were produced from the variety Express. On the other hand, the cultivar Licord achieved the smallest value of stearic acid (1.86\%) followed Licrown it statically group. According to Hassan et al. (2005) observed that significant differences for saturated fatty acids were due to the variances of the genotypes. However, the saturated fatty acids content in oil were affected by genotype (Isleib et al., 2008).

Table 3. Analysis of variance and means of some quality properties of canola genotypes

\begin{tabular}{|c|c|c|c|c|c|c|c|c|c|c|c|c|c|c|c|c|c|c|c|}
\hline 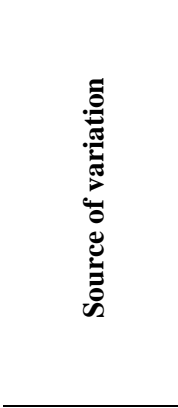 & $\breve{a}$ & 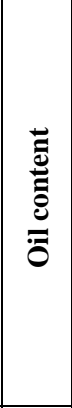 & 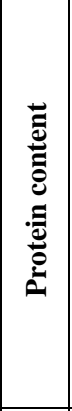 & 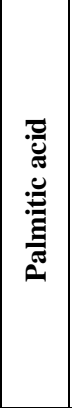 & 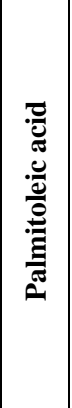 & 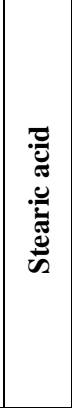 & 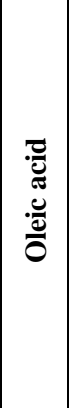 & 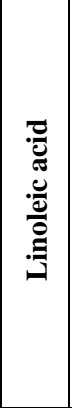 & 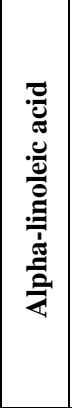 & 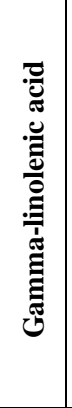 & 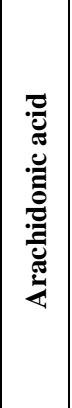 & 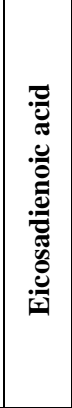 & 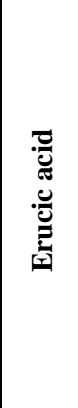 & 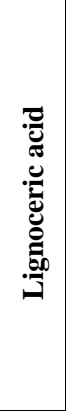 & 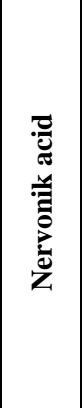 & 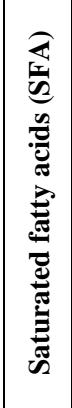 & 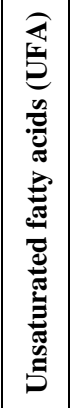 & 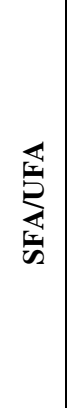 & 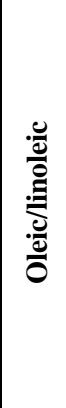 \\
\hline Block (B) & 2 & - & - & - & - & - & - & - & - & - & - & - & - & - & - & - & - & - & - \\
\hline Year (Y) & 1 & ns & $*$ & $\mathrm{~ns}$ & $* *$ & $* *$ & ns & ns & $\mathrm{ns}$ & ns & ns & $\mathrm{ns}$ & $*$ & ns & ns & ns & $\mathrm{ns}$ & $\mathrm{ns}$ & ns \\
\hline Cultivars (C) & 2 & ns & ns & $*$ & ns & $* *$ & $* *$ & $* *$ & ns & $*$ & $* *$ & $*$ & ns & $*$ & ns & $* *$ & ns & $* *$ & $* *$ \\
\hline Y $\times C$ & 2 & $*$ & $*$ & ns & $*$ & ns & ns & $*$ & $\mathrm{~ns}$ & ns & ns & ns & ns & ns & ns & $\mathrm{ns}$ & ns & ns & ns \\
\hline Error & 10 & & & & & & & & & & & & & & & & & & \\
\hline $\mathrm{CV}$ & & 2.31 & 5.03 & 4.05 & 2.77 & 4.57 & 0.64 & 1.27 & 5.88 & 9.04 & 4.63 & 9.92 & 11.06 & 8.87 & 10.11 & 0.83 & 0.14 & 0.96 & 1.80 \\
\hline
\end{tabular}

ns: not significant, *significant at $\mathrm{P}<0.05$, **significant at $\mathrm{P}<0.01$ 
Table 4. Response of canola cultivars on protein and oil fatty acid contents

\begin{tabular}{|c|c|c|c|c|c|c|c|c|c|}
\hline \multirow{2}{*}{ Cultivars } & \multicolumn{3}{|c|}{ Oil content (\%) } & \multicolumn{3}{|c|}{ Protein content $(\%)$} & \multicolumn{3}{|c|}{ Palmitic acid (\%) } \\
\hline & 2013/14 & 2014/15 & Mean & 2013/14 & $2014 / 15$ & Mean & 2013/14 & $2014 / 15$ & Mean \\
\hline Express & 36.27 & 38.60 & 37.43 & 20.62 & 23.91 & 22.26 & 4.68 & 4.66 & $4.67 \mathrm{~b}$ \\
\hline Licord & 38.33 & 37.50 & 37.92 & 21.57 & 23.40 & 22.48 & 4.19 & 4.42 & $4.30 \mathrm{~b}$ \\
\hline Licrown & 38.10 & 37.70 & 37.90 & 23.74 & 23.15 & 23.44 & 4.52 & 4.49 & $4.50 \mathrm{ab}$ \\
\hline Mean & 37.57 & 37.93 & 37.75 & 21.98 & 23.48 & 22.73 & 4.46 & 4.52 & 4.92 \\
\hline LSD & - & 0.87 & - & - & - & - & - & - & 0.23 \\
\hline \multirow{2}{*}{ Cultivars } & \multicolumn{3}{|c|}{ Palmitoleic acid (\%) } & \multicolumn{3}{|c|}{ Stearic acid (\%) } & \multicolumn{3}{|c|}{ Oleic acid (\%) } \\
\hline & 2013/14 & 2014/15 & Mean & 2013/14 & $2014 / 15$ & Mean & 2013/14 & $2014 / 15$ & Mean \\
\hline Express & 0.173 & 0.177 & 0.175 & 1.99 & $2.12 \mathrm{a}$ & $2.06 \mathrm{a}$ & 65.2 & $65.8 \mathrm{a}$ & $65.5 \mathrm{a}$ \\
\hline Licord & 0.160 & 0.180 & 0.170 & 1.74 & $1.98 \mathrm{~b}$ & $1.86 \mathrm{~b}$ & 64.4 & $64.9 \mathrm{~b}$ & $64.6 \mathrm{~b}$ \\
\hline Licrown & 0.173 & 0.177 & 0.175 & 1.87 & $1.95 \mathrm{~b}$ & $1.91 \mathrm{~b}$ & 64.2 & $64.4 \mathrm{c}$ & $64.3 \mathrm{~b}$ \\
\hline Mean & 0.169 & 0.178 & 0.173 & 1.87 & 2.02 & 1.94 & 64.6 & 65 & 64.8 \\
\hline $\mathbf{L S D}_{\mathbf{v}}$ & - & - & - & - & 0.06 & 0.11 & - & 0.4 & 0.54 \\
\hline \multirow{2}{*}{ Cultivars } & \multicolumn{3}{|c|}{ Linoleic acid (\%) } & \multicolumn{3}{|c|}{ Alpha-linoleic acid (\%) } & \multicolumn{3}{|c|}{ Gamma-linolenic acid (\%) } \\
\hline & $2013 / 14$ & 2014/15 & Mean & 2013/14 & 2014/15 & Mean & 2013/14 & 2014/15 & Mean \\
\hline Express & $17.37 \mathrm{~b}$ & $16.96 \mathrm{c}$ & $17.17 \mathrm{~b}$ & 1.2 & 1.24 & 1.22 & 0.706 & 0.747 & $0.727 \mathrm{a}$ \\
\hline Licord & $18.23 \mathrm{a}$ & $17.80 \mathrm{~b}$ & $18.01 \mathrm{a}$ & 1.15 & 1.11 & 1.13 & 0.567 & 0.653 & $0.610 \mathrm{~b}$ \\
\hline Licrown & $17.93 \mathrm{~b}$ & $18.24 \mathrm{a}$ & $18.09 \mathrm{a}$ & 1.22 & 1.13 & 1.17 & 0.653 & 0.653 & $0.653 \mathrm{a}$ \\
\hline Mean & 17.84 & 17.67 & 17.75 & 1.19 & 1.16 & 1.17 & 0.642 & 0.684 & $0.663 a$ \\
\hline $\mathbf{L S D}_{\mathbf{v}}$ & 0.48 & 0.16 & 0.29 & - & - & - & - & - & 0.077 \\
\hline
\end{tabular}

In each column, means followed by the same letter within columns are not significantly different $(\mathrm{P}<0.01)$ according to Tukey test, ns: not significant

Generally, in case of average values of both years, the variety Express achieved the smallest value $(12.63 \%)$, while, the cultivar Licrown generated the greatest $(12.97 \%)$ saturated fatty acid. In contrary, the maximum value $(85.47 \%)$ and the minimum values $(85.14 \%)$ of unsaturated fatty acid were observed in the variety Express and Licrown, respectively. Accordingly, the variety 'Express' achieved the highest rate for saturated fatty acids/unsaturated fatty acids (6.75\%) and oleic/linoleic (3.82\%). The potential impact of seed maturity is dependent on genotype, climatic conditions, and genotype/climate interactions was reported by (Onat et al., 2017). Lower temperature during the seed development normally is associated with more unsaturated oil due to the increased activity of oleatedesaturase, which promotes the synthesis of linoleic acid (Bovi, 1982). The increase in oleic acid with seed maturity is normally accompanied by a decrease in palmitic, linoleic, arachidic, eicosenic, behenic and lignoceric acid (Holaday and Pearson, 1974).

Concerning, the Erucic concentration, Erucic acid is one of the most essential fatty acids within Brassica genus. Low or zero erucic acid contents are desirable in edible oil. Data in Table 5 revealed that the amount of Erucic percentage in all canola cultivars used ranged from the lowest (0.182) in Express to the highest $(0.252$ and 0.243 ) in Licord and Licrown. These results were supported by another investigations finding, who reported that, the safe limits for these compounds have been described as less than 2\% of erucic acid in oil (Grombachr and Nelson, 1992; El sabah et al., 2016). 
Table 5. Response of canola cultivars on oil fatty acid contents

\begin{tabular}{l|c|c|c|c|c|c|c|c|c}
\hline \multirow{2}{*}{ Cultivars } & \multicolumn{3}{|c|}{ Arachidonic acid (\%) } & \multicolumn{2}{c|}{ Eicosadienoic acid (\%) } & \multicolumn{3}{c}{ Erucic acid (\%) } \\
\cline { 2 - 10 } & $\mathbf{2 0 1 3 / 1 4}$ & $\mathbf{2 0 1 4 / 1 5}$ & Mean & $\mathbf{2 0 1 3 / 1 4}$ & $\mathbf{2 0 1 4 / 1 5}$ & Mean & $\mathbf{2 0 1 3 / 1 4}$ & $\mathbf{2 0 1 4 / 1 5}$ & Mean \\
\hline Express & $5.85 \mathrm{~b}$ & $5.60 \mathrm{~b}$ & $5.73 \mathrm{~b}$ & 0.380 & 0.387 & $0.383 \mathrm{a}$ & 0.203 & 0.160 & 0.182 \\
Licord & $6.71 \mathrm{a}$ & $6.26 \mathrm{a}$ & $6.48 \mathrm{a}$ & 0.313 & 0.333 & $0.323 \mathrm{~b}$ & 0.243 & 0.260 & 0.252 \\
Licrown & $6.45 \mathrm{a}$ & $6.33 \mathrm{a}$ & $6.39 \mathrm{a}$ & 0.357 & 0.347 & $0.352 \mathrm{ab}$ & 0.313 & 0.173 & 0.243 \\
Mean & 6.34 & 6.06 & 6.20 & 0.350 & 0.355 & 0.352 & 0.350 & 0.198 & 0.225 \\
LSD $_{\text {vear }}$ & 0.59 & 0.21 & 0.36 & - & - & 0.045 & 0.076 & - & - \\
\hline
\end{tabular}

\begin{tabular}{l|c|c|c|c|c|c|c|c|c}
\hline \multirow{2}{*}{ Cultivars } & \multicolumn{3}{|c|}{ Lignoceric acid (\%) } & \multicolumn{3}{c|}{ Nervonik acid (\%) } & \multicolumn{3}{c}{ Saturated fatty acids (SFA) (\%) } \\
\cline { 2 - 10 } & $\mathbf{2 0 1 3 / 1 4}$ & $\mathbf{2 0 1 4 / 1 5}$ & Mean & $\mathbf{2 0 1 3 / 1 4}$ & $\mathbf{2 0 1 4 / 1 5}$ & Mean & $\mathbf{2 0 1 3 / 1 4}$ & $\mathbf{2 0 1 4 / 1 5}$ & Mean \\
\hline Express & 0.177 & 0.180 & $0.178 \mathrm{a}$ & 0.127 & 0.123 & 0.125 & 12.70 & $12.56 \mathrm{~b}$ & $12.63 \mathrm{c}$ \\
Licord & 0.143 & 0.157 & $0.150 \mathrm{~b}$ & 0.133 & 0.120 & 0.127 & 12.79 & $12.81 \mathrm{a}$ & $12.80 \mathrm{~b}$ \\
Licrown & 0.173 & 0.163 & $0.168 \mathrm{ab}$ & 0.140 & 0.120 & 0.130 & 13.01 & $12.94 \mathrm{a}$ & $12.97 \mathrm{a}$ \\
Mean & 0.164 & 0.167 & 0.165 & 0.133 & 0.121 & 0.127 & 12.83 & 12.77 & 12.80 \\
LSD $_{\text {vear }}$ & - & - & 0.019 & - & - & - & - & 0.13 & 0.14 \\
\hline
\end{tabular}

\begin{tabular}{l|c|c|c|c|c|c|c|c|c}
\hline \multirow{2}{*}{ Cultivars } & \multicolumn{3}{|c|}{ Unsaturated fatty acids (\%) } & \multicolumn{3}{c|}{ UFA/SFA (\%) } & \multicolumn{3}{c}{ Oleic/linoleic (\%) } \\
\cline { 2 - 10 } & $\mathbf{2 0 1 3 / 1 4}$ & $\mathbf{2 0 1 4 / 1 5}$ & Mean & $\mathbf{2 0 1 3 / 1 4}$ & $\mathbf{2 0 1 4 / 1 5}$ & Mean & $\mathbf{2 0 1 3 / 1 4}$ & $\mathbf{2 0 1 4 / 1 5}$ & Mean \\
\hline Express & 85.39 & $85.56 \mathrm{a}$ & $85.47 \mathrm{a}$ & 6.70 & $6.80 \mathrm{a}$ & $6.75 \mathrm{a}$ & $3.75 \mathrm{a}$ & $3.88 \mathrm{a}$ & $3.82 \mathrm{a}$ \\
Licord & 85.21 & $85.34 \mathrm{ab}$ & $85.27 \mathrm{ab}$ & 6.66 & $6.64 \mathrm{~b}$ & $6.65 \mathrm{~b}$ & $3.53 \mathrm{~b}$ & $3.65 \mathrm{~b}$ & $3.59 \mathrm{~b}$ \\
Licrown & 85.03 & $85.25 \mathrm{~b}$ & $85.14 \mathrm{~b}$ & 6.63 & $6.67 \mathrm{c}$ & $6.65 \mathrm{c}$ & $3.58 \mathrm{~b}$ & $3.53 \mathrm{c}$ & $3.55 \mathrm{~b}$ \\
Mean & 85.21 & 85.38 & 85.29 & 6.63 & 6.67 & 6.65 & 3.62 & 3.68 & 3.65 \\
LSD $_{\text {vear }}$ & - & 0.21 & 0.21 & - & 0.06 & 0.08 & 0.13 & 0.05 & 0.08 \\
\hline
\end{tabular}

In each column, means followed by the same letter within columns are not significantly different $(\mathrm{P}<0.01)$ according to Tukey test, ns: not significant

The differences in the fatty acids among cultivars are due to differential growth habit, environmental factors and genetic variations. The statistically analysis of data indicated that cultivars differed significantly for oil content among cultivars, locations and their interactions in present study was confirmed the earlier by (Pritchard et al., 2000). Oil content of canola depends on several factors such as variety, growth conditions and fertilization (Laaniste et al., 2004). Bengtsson (1988) recorded 9\% difference between two cultivars of winter canola, while, it was reported less difference of $2.3 \%$ between different Brassica carinata lines for seed oil content (Gentent et al., 1966). The protein contents of cultivar examined in the study varied between 21.98 to $23.48 \%$. The protein content may be affected by environmental conditions (Barszczak et al., 1993), and Sargin (2012) noted that the variation largely depends on the genetic properties of variety.

The various cultivars of canola crop are differed to fatty acid under the current environments. It was observed that the most important fatty acid in rapeseed is oleic acid with $70-80 \%$ (Schierholt, 2000). Although the low level of palmitic acid and other saturated fatty acids (less than 5\%) in canola oil is considered to be nutritionally desirable (Kay, 1988). In this concern McCartney et al. (2004) found that the major of the variation in the palmitic (C16:0) due to the impact of genotypic. The oil composition in peanut is affected by different factors involving environmental factors, genetic factors, and interaction between environmental and genetic factors (Mzimbiri et al., 2014; Gulluoglu et al., 2016). Fatty acid composition is the function of genotype, climate conditions, morphology and physiology as well as crop management (Arsalan, 2007). 


\section{Conclusion}

The results of the study suggested that, that all cultivars have a good potential for the winter season of Southeastern Anatolia of Turkey. Regarding the production, all cultivars were surpassed in yield as well as, others quality parameters such as high oleic, linoleic (Express) as well as high content in unsaturated Fatty Acids SFA/UFA. All cultivars produced low erucic acids, while the cultivar 'Licord' produced low linolenic acid content. The cultivar, 'Express' was produced a high oleic and linoleic acid content and these findings could be useful in maintaining the required yield and quality attributes of canola cultivars under investigation condition for future breeding programs.

\section{REFERENCES}

[1] Abdelaal, A. A. K, Hafez, Y. M., El Sabagh, A. (2017): Ameliorative effects of abscisic acid and yeast on morpho-physiological and yield characters of maize (Zea mays L.) plants under water deficit conditions. - Fresenius Environmental Bulletin 26(12): 7372-7383.

[2] Akdeniz, H., Koc, A., Islam, M. S., El Sabahg, A. (2018a): Performances of hairy vetch varieties under different locations of Mediterranean environment. - Fresenius Environmental Bulletin 27(6): 4263-4269.

[3] Akdeniz, H., Koç, A., Hossain, A., El Sabagh, A. (2018b): Nutritional values of four hairy vetch(vicia villosa roth) varieties grown under Mediterranean environment. Fresenius Environmental Bulletin 27(8): 5385-5390.

[4] Anonymous (1992): Annual Report. - Ayub Agricultural Research Institute, Faisalabad, Pakistan.

[5] Anonymous (2002): The Biology and Ecology of Canola (Brassica napus). - Office of the Gene Technology Regulator. http://www.ogtr.gov.au/internet/ogtr/publishing.nsf/content/ canola3/\$FILE/brassica.pdf.

[6] A. O. A. C. (2000): Official and Tentative Methods of Analysis, 2nd Ed. - Association of Official Agricultural Chemists, Washington, DC, USA.

[7] Arsalan, B. (2007): The determination of oil and fatty acid compositions of domestic and exotic safflower (Carthamus tinctorius L.) genotypes and their interactions. - Journal of Agronomy 6(3): 415420.

[8] Atakişi, İ. K. (1977): Çukurova'da Yetiştirilebilecek Kolza Çeşitlerinin Önemli Tarımsal ve Kalite Özellikleri Üzerine Araştırmalar (Studies on agronomic and quality characteristics of rapeseed cultivars to be grown in Çukurova). - Çukurova Üniv. Zir. Fak. Yıllığ1 1: 27-55.

[9] Baghdadi, H., Taspinar, S., Yousefi, M., Hosseinpour, A. (2013): Influence of different sowing dates on grain yield of Canola (Brassica napus L.) cultivars Inqazvin area. International Journal of Agriculture: Research and Review 2(S): 10921096.

[10] Barszczak, Z., Barszczak, T., Foy, C. D. (1993): Effect of moisture nitrogen rates and soil acidity on seed yields and chemical composition of winter rape cultivars. - Journal of Plant Nutrition 16(1): 85-86.

[11] Barutçular, C., EL Sabagh, A., Koç, M., Ratnasekera, D. (2017): Relationships between grain yield and physiological traits of durum wheat varieties under drought and high temperature stress in Mediterranean conditions. - Fresenius Environmental Bulletin 26(6): 4282-4291.

[12] Bengtsson, A. (1988): Current winter rape cultivars. - Aktulla Hostrapssorter, Svensk Frotidning 57: 115-117. 
[13] Bovi, M. L. A. (1982): Genotypic and environmental effect on fatty acid composition, iodine value and oil content of peanut (Arachis hypogeal L.). - Ph.D. Dissertation. University of Florida.

[14] Coşgun, B., Ö, Öztürk. (2014): Determination of yield and some quality characteristics of winter canola (Brassica napus ssp. oleifera L.) cultivars. - International Journal of Biological, Veterinary, Agricultural and Food Engineering 8(9): 949-955.

[15] El Habbasha, E. S. F., El Salam, M. A. (2009). Response of two canola varieties (Brassica napus L.) to nitrogen fertilizer levels and zinc foliar application. - Proceedings of the International Plant Nutrition Colloquium XVI. Department of Plant Sciences, UC Davis. http://eprints.cdlib.org/uc/item/68f0h22d.

[16] El Sabagh, A., Omar, A., Saneoka, H., Barutçular, C. (2016): Role of integrated use of nitrogen fertilizer sources in improving seed quality of canola (Brassica napus L.). Turkish Journal of Agriculture-Food Science and Technology 4: 73-78.

[17] El Sabagh, A., Abdelaal, K. A., Barutcular, C. (2017): Impact of antioxidants supplementation on growth, yield and quality traits of canola (Brassica napus L.) under irrigation intervals in north Nile Delta of Egypt. - Journal of Experimental Biology and Agricultural Sciences 5(1): 163-172.

[18] El Sabagh, A., Hossain., A., Barutçular, C., Islam, M. S., Ratnasekera, D., Kumar, N., Meena, R.S., Gharib, H. S., Saneoka, H., Teixeira da Silva, J. A. (2018): Drought and salinity stress management for higher and sustainable canola (Brassica napus L.) production: a critical review. - Australian Journal of Crop Science [in press].

[19] Eskandari, H., Kazemi, K. (2012): Changes in germination properties of (Brassica napus L.) as affected by hydro priming of seeds. - Journal of Basic and Applied Scientific Research 2: 3285-3288.

[20] Food and Agriculture Organization of the United Nations Statistical Databases FAO (2018): http://www.fao.org/statistics/en/ - Accessed on 10 April 2018

[21] Friedt, W., Snowdon, R. J. (2009): Oilseed Rape. - In: Vollmann, J., Rajcan, I. (eds.) Handbook of Plant Breeding. Oil Crops, Springer, New York, pp. 91-126.

[22] Gentent, A., Rakow, G., Roney, J. P., Downey, R. K. (1966): Agronomic performance and seed quality of Ethiopian mustard in Saskatchewan. - Can. J. Plant Sci. 76: 387-392.

[23] Gheorghe, C., Raus, L., Coroi, I., Gales, D., Jitareanu, G. (2013): Effect of tillage and cultivar on winter Oilseed Rape (Brassica napus L.) yield and economic efficiency in Suceava Plateau. - Pro-Environment 6: 130135.

[24] Gormus, O., Harun, R., El Sabagh, A. (2017a): Impact of defoliation timings and leaf pubescence on yield and fiber quality of cotton. - Journal of Agricultural Science and Technology 19(4): 903-915.

[25] Gormus, O., El Sabagh, A., Harun, R., Islam, M. S. (2017b): Enhancement of productivity and fiber quality by defining ideal defoliation and harvesting timing in cotton. - Romanian Agricultural Research 34: 226-232.

[26] Grombachr, A., Nelson, L. (1992): Canola Production. - University of Nebraska, Lincoln.

[27] Gül, M. K., Egesel, C. Ö., Tayyar, Ş., Türk, F. M. (2005): Kışlık kolza çeşitlerinde tohum ve tohum kalitesi ile ilgili bazı özelliklerin incelenmesi ve yetiştirilme olanakları. Türkiye 6. Tarla Bitkileri Kongresi, 05-09 Eylül 2005 Antalya, pp. 229-231.

[28] Gulluoglu, L., Bakal, H., Onat, B., El Sabagh, A., Arioglu, H. (2016): Characterization of peanut (Arachis hypogeal L.) seed oil and fatty acids composition under different growing season under Mediterranean environment. - Journal of Experimental Biology and Agricultural Sciences 4(5S): 564-571.

[29] Hassan, F., Manaf, A., Ejaz, M. (2005): Determinants of oil and fatty acid accumulation in peanut. - International Journal of Agriculture and Biology. 7(6): 895-899.

[30] Holaday, C. E., Pearson, J. L. (1974): Effects of genotype and production area on the fatty acid composition, total oil and protein in peanuts. - Journal of Food Science 39(6): 1206-1209. DOI: 10.1111/j.1365-2621.1974.tb07355.x. 
[31] İkiel, C., Kaymaz, B. (2005): Climatic conditions impact on canola cultural plant growing in Turkey. - http://web.sakarya.edu.tr/cikiel/climatic-conditions-impact-on canola cultural-plant-growing-in-turkey.pdf.

[32] Isleib, T. G., Tilman, B. L., Patte, H. E., Sanders, T. H., Hendrix, K. W., Dean, L. O. (2008): Genotype-by-environment interaction for seed composition traits of breeding lines in the uniform peanut performance test. - Peanut Science 35: 130-138.

[33] Joughi, E., Samadzadeh, G., Hervan, E., Majidi, A. H., Rad, S., Noormohamadi, G. H. (2018): Fatty acid composition of oilseed rapeseed genotypes as affected by vermicompost application and different thermal regimes. - Agronomy Research 16(1): 230-242.

[34] Kay, E. M. (1988): Lipid oxidation stability of low linolenic canola cultivars and determination by HPLC analysis. - Ph.D Thesis, Univ. of Saskatchewan, Saskatoon, Canada.

[35] Khehra, M. K., Singh, P. (1988): Sensitivity and performance of some Brassica napus genotypes in stress and non-stress environments. - Crop Improvement Ind. 15: 209-211.

[36] Laaniste, P., Joudu, J., Eremeev, V. (2004): Oil content of spring oilseed rape seeds according to fertilisation. - Agronomy Journal 2(1): 83-86.

[37] McCartney, C. A., Scarth., R., McVetty, P. B. E., Daun, J. K. (2004): Genotypic and environmental effects on fatty acid concentration of canola grown in Manitoba. - Can. J. Plant Sci. 84: 749-758.

[38] Molazem, D., Azimi, J., Dideban, T. (2013): Measuring the yield and its components, in the Canola in different planting date and plant density of the west Guilan. - International Journal of Agriculture and Crop Sciences 6(12): 869-872.

[39] Mzimbiri, R., Shi, A. M., Liu, H., Wang, Q. (2014): Peanut fatty acids determination using hyper spectroscopy imagine and its significance on food quality and safety. - Food Science and Quality Management 28: 90-97.

[40] Onat, B., Bakal, H., Arioğlu, H., Bozdoğan, A., Kafkas, E., El Sabagh, A. (2017): Comparison of volatile composition of raw and roasted halisbey peanut variety using HSSPME GC/MS techniques. - Fresenius Environmental Bulletin 26(8): 5198-5204.

[41] Öztürk, Ö. (2010): Effects of source and rate of nitrogen fertilizer on yield, yield components and quality of winter rapeseed (Brassica napus L.). - Chilean Journal of Agricultural Research 70(1): 132-141.

[42] Pritchard, F. M., Eagles, H. A., Norton, R. M., Salisbury, P. A., Nicolesa, M. (2000): Environmental effects on seed composition of Victorian canola. - Australian Journal of Experimental Agriculture 40: 679-685.

[43] Sana, M., Ali, A., Malik, M. A., Saleem, M. F., Rafiq, M. (2003): Comparative yield potential and oil contents of different canola cultivars (Brassica napus L.). - Pakistan Journal of Agronomy 2(1): 1-7.

[44] Sargın, O. (2012): Bitki sıklı̆̆ının kışlık kolza çeşitlerinde verim, verim komponentleri ve yağ oranı üzerine etkisi. - Yüksek Lisans Tezi, Ordu Üniversitesi Fen Bilimleri Enstitüsü, Ordu.

[45] Schierholt, A. (2000): Hoher olsaeuregehalt im samenool, genetische charakterisierung von mutanten im winterraps (Brassica napus). - $\mathrm{PhD}$ Dissertation, University of Geottingen, Cuvlillier.

[46] Slover, H. T., Lanza, E. (1979): Quantitative analysis of food fatty acids by capillary gas chromatography. - J Am Oil Chem Soc 56: 933-943.

[47] Stringam, G. R., Degenhardt, D. F., Thalgarajah, M. R., Bansal, V. K., Hawklns, G. P. (2002): Kelsey summer rape. - Can. J. Plant Sci. 82: 559-560.

[48] Yıldırım, M., Barutçular, C., Hossain, A., Koç, M., Dizlek, H., Akinci, C., Toptaş, I., Basdemir, F., Islam, M. S., El Sabagh, A. (2018): assessment of the grain quality of wheat genotypes grown under multiple environments using GGE biplot analysis. Fresenius Environmental Bulletin 27(7): 4830-4837.

[49] Zhang, H. P., Berger, J. D., Milroy, S. (2011): Genotype x environment interaction of canola (Brassica napus L) in multi-environment trials.-17th Australian Research Assembly on Brassicas, Wagga Wagga, New South Wales, Australia. 